\title{
Abordagem dos pedículos glissonianos no manejo do trauma hepático
}

\section{Glissonian approach to the management of liver trauma}

\author{
Marcelo A. F. Ribeiro Jr ${ }^{1}$, Francine Papaiordanou ${ }^{2}$, Marina G. Epstein ${ }^{3}$, Eleazar Chaib ${ }^{4}$
}

\begin{abstract}
RESUMO
OBJETIVO: Investigar uma abordagem diferente no manejo do trauma hepático, que consiga preservar o máximo possível o parênquima do órgão, expondo apenas a área lesada à isquemia e posterior reperfusão. METODOLOGIA: Pesquisa de artigos publicados nas bases de dados MedLine e pubMed no período de 1980 a 2010, sobre a abordagem dos pedículos glissonianos, e usando como palavras de busca: fígado, cirurgia, trauma, veia porta e artéria hepática. RESULTADOS: A abordagem dos pedículos glissonianos é viável, não demanda de técnica cirúrgica elaborada, e a chave para o sucesso é ter um conhecimento anatômico do órgão, incluindo pontos importantes em sua superfície para que o cirurgião consiga obter o controle rápido de toda a área lesada sem comprometer o fluxo sanguíneo para as áreas sadias. CONCLUSÃO: A abordagem glissoniana representa uma ferramenta que pode ser utilizada com segurança no cenário de um trauma hepático, para minimizar as complicações relacionadas a ressecção não anatômica do parênquima e ligaduras realizadas às cegas.
\end{abstract}

Palavras-Chave: Fígado. Trauma. Cirurgia. Veia porta. Artéria Hepática.

\section{INTRODUCTION}

Abdominal trauma represents one of the main causes of death in patients sustaining trauma, and liver traumatic injury occurs in approximately $5 \%$ of all trauma admissions ${ }^{1}$. Due to its anatomic location un- der the right costal margin and size, make it susceptible for both blunt and penetrating trauma.

In the last few decades several different ways to approach the liver either operatively and nonoperatively have been described improving the results and decreasing the mortality rates. However, the most
1- Mestre e Doutor em Cirurgia pela UNIFESP - EPM, Professor Titular e Chefe do Núcleo de Clínica Cirúrgica da Universidade de Santo Amaro - UNISA, Coordenador do Curso de Medicina da Universidade de Santo Amaro - UNISA, Professor de Habilidades Cirúrgicas da Universidade Cidade de São Paulo - UNICID.

2- Acadêmica do Sexto Ano do Curso de Medicina da Universidade Cidade de São Paulo - UNICID

3-Residente de Cirurgia Geral da Universidade Santo Amaro UNISA

4- Professor Livre Docente pela FMUSP-SP. Medico assistente do Serviço de Transplante de Fígado do HC-FMUSP.
Correspondência: mribeiro@ cwaynet.com.br Telephone: 55-11-2141-8565. Endereço : Rua Nova York, 609 apto 122 B. São Paulo, Brazil.

Artigo recebido em 07/12/2010 Aprovado para publicação em 28/01/2011 
severe liver parenchymal and venous injuries continue to challenge the trauma or hepatobiliary surgeons and often lead to death.

The American Association for the Surgery of Trauma (AAST) described a well known classification to hepatic injuries ${ }^{2}$ that can help the surgeon to decide the best approach to each of these injuries (table I).

In elective liver surgery, especially for cancer or benign liver diseases, there is a modern concept in which the surgeon is trying to preserve as much liver parenchyma as possible to permit if necessary in the future another liver resection with safety and small risk of hepatic liver failure due to an inadequate liver remnant. In normal livers, the minimum volume to be preserved must be $20 \%$ in normal conditions for an elective case, in cirrhosis the minimum acceptable number is $40 \%{ }^{3}$. Obviously the surgeon must take into consideration other injuries and especially hemodynamic conditions that may lead to an increased chance of ischemic and posterior reperfusion injury to the parenchyma that in some patients may impair the organ regeneration.

\section{MATERIAL AND METHODS}

Medline and pubMed search from 1980 to 2010 about the glissonian approach , including, liver, surgery, trauma, portal vein and hepatic artery as keywords.

\section{RESULTS}

\section{ANATOMICAL CONSIDERATIONS}

Traditionally the liver has been divided into two lobes, as described by Cantlie in 1898, the left lobe that includes the hepatic tissue to the left of the falciform ligament along with the quadrate and caudate lobes. The right lobe consists of the remaining parenchyma.

Here we identify a potential problem when classifying the liver trauma, the fact that the so called left liver for example represents no more than usually $40 \%$ of the total liver volume. In practical terms when a grade IV or V injury is described, we may under or even over estimate the magnitude of the problem, es-

Table I

Grades of lesions and injury description

\begin{tabular}{|c|c|}
\hline Grade & Injury description \\
\hline I - Hematoma & $\begin{array}{l}\text { Subcapsular, nonexpanding, }<10 \mathrm{~cm} \text { surface area } \\
\text { Capsular tear, nonbleeding, }<1 \mathrm{~cm} \text { parenchymal bleeding }\end{array}$ \\
\hline \multicolumn{2}{|l|}{ Laceration } \\
\hline II - Hematoma & $\begin{array}{l}\text { Subcapsular, nonexpanding, } 10 \text { to } 50 \% \text { surface areaIntraparenchymal nonexpanding }<10 \mathrm{~cm} \\
\text { surface area } \\
\text { Capsular tear, active bleeding, } 1 \text { to } 3 \mathrm{~cm} \text { parenchymal depth }<10 \mathrm{~cm} \text { in length }\end{array}$ \\
\hline \multicolumn{2}{|l|}{ Laceration } \\
\hline III- Hematoma & $\begin{array}{l}\text { Subcapsular, nonexpanding, }>50 \% \text { surface area or expanding } \\
\text { Ruptured subcapsular hematoma with active bleeding } \\
\text { Intraparenchymal hematoma }>10 \mathrm{~cm} \text { or expanding }\end{array}$ \\
\hline Laceration & $\begin{array}{l}\text { Capsular tear, active bleeding, } 1 \text { to } 3 \mathrm{~cm} \text { parenchymal depth }<10 \mathrm{~cm} \text { in length } \\
>3 \mathrm{~cm} \text { parenchymal depth }\end{array}$ \\
\hline IV- Hematoma & Ruptured intraparenchymal hematoma with active bleeding \\
\hline Laceration & Parenchymal disruption involving 25 to $75 \%$ of hepatic lobe \\
\hline V-Laceration & Parenchymal disruption involving $>75 \%$ of hepatic lobe \\
\hline Vascular & Justahepatic venous injuries (i.e., retrohepatic vena cava) \\
\hline VI- Vascular & Vascular avulsion \\
\hline
\end{tabular}


pecially when a surgical removal of the parenchyma may be necessary.

Based on these facts the modern concepts of liver surgery follows the definition of the functional liver anatomy in which the parenchyma is divided into segments based on the distribution of the glissonian pedicles and hepatic veins. The liver may be submitted to surgical resection and any of its eight segments can be removed safely without compromising the rest of its functional system.

In order to achieve the glissonian approach to handle liver trauma, the trauma surgeon must be familiar with the topographic liver anatomy since the landmarks to get each of the pedicles is basically based on superficial reference points.

\section{THE GLISSONIAN APPROACH}

In 1989 Galperin and Karagiulian ${ }^{4}$ described a technique for the isolation of portal pedicles through an extraglissonian approach. In 1992 Launois and Jamieson $^{5}$ described the intrahepatic posterior approach to the structures of the portal triad for right hepatectomies or right-sided segmentectomies. Later in 2003, Machado et $\mathrm{al}^{6}$ described a modified technique of the intrahepatic posterior approach that permits the identification and isolation of the glissonian sheaths without hilar clamping or digital maneuvers.

Considering the fact that the majority of the hepatic injuries today are carryout in a non-operative manner, the surgical approach has been reserved to patients in two distinct clinical scenarios: the ones who arrive with hemodinamical instability and evidences of either blunt or penetrating abdominal trauma compromising the liver or the ones who the conservative therapy fails. Usually these patients sustains grades IV or $\mathrm{V}$ of hepatic lesions.

From these cases, $90 \%$ of the penetrating and $60 \%$ of the blunt injuries will require only simple surgical maneuvers and the other $10 \%$ of penetrating and $40 \%$ of blunt cases will demand from the surgeon advanced liver surgical skills ${ }^{7}$.

In these specific situations the use of refined surgical skills will allow the surgeon to remove only the injured area without compromising the remnant liver, plus will permit an adequate and selective approach to the large branches of the hepatic veins as well as other vascular structures avoiding ischemic areas diminishing the risk of liver abscesses, ischemic injuries to the bile ducts and other complications.
The propose technique must be done following a sequence of steps as described below:

1- First step: Evacuate all clots and blood, get a pringle maneuver prepare in case its needed and divide the ligaments. To control the bleeding site proceed a damage control maneuver by the use of surgical pads from without creating two opposing pressure vectors that compress the injured tissue between them. Another option when the surgeon faces a hole into the liver parenchyma is to pack it from within stuffing a crevice or an actively bleeding cavity with absorptive gauze.

2- Once the surgeon accomplish bleeding control he/ she must identify the pattern of the injury, its location and characteristics. A solid knowledge of the topographic anatomy of the liver is required in order to decide which will be the best glissonian approach based on the branches to be controlled and without insult the rest of the non-injured liver parenchyma.

3- Right Side6.

a. The portal triad is pulled downward without clamping or dissecting these structures individually. If the gallbladder is in place, cholecystectomy must be performed in order to achieve the glissonian pedicles. A small anterior incision is made in front of the hilum (A in FIGURE 1). The hepatic parenchyma is divided by blunt dissection to disclose the anterior surface of the right glissonian pedicles and its limits. A second incision is made perpendicular to the hepatic hilum in the segment VII, where it connects to caudate lobe (B in figure 1). A large curved clamp (Mixter or Gray) is introduced through the left side of the right glissonian sheath, with the tip of the instrument allowed to slide from left to right diagonally at a 30o angle to place a tape around the right main sheath. This precludes incision of the caudate lobe, avoiding damage to its vessels. A third incision ( $\mathrm{C}$ in figure 1 ) is performed on the right edge of the gallbladder bed and permits access to the right anterior pedicle when the clamp is inserted through the first incision in a 60 o angle (Figures 2). By combining the second and third liver incisions it is possible to isolate the right posterior pedicle. All of these steps are performed without the Pringle maneuver.

b. Mobilize the left lobe by detaching its ligaments falciform, left triangular and coronary. The left 


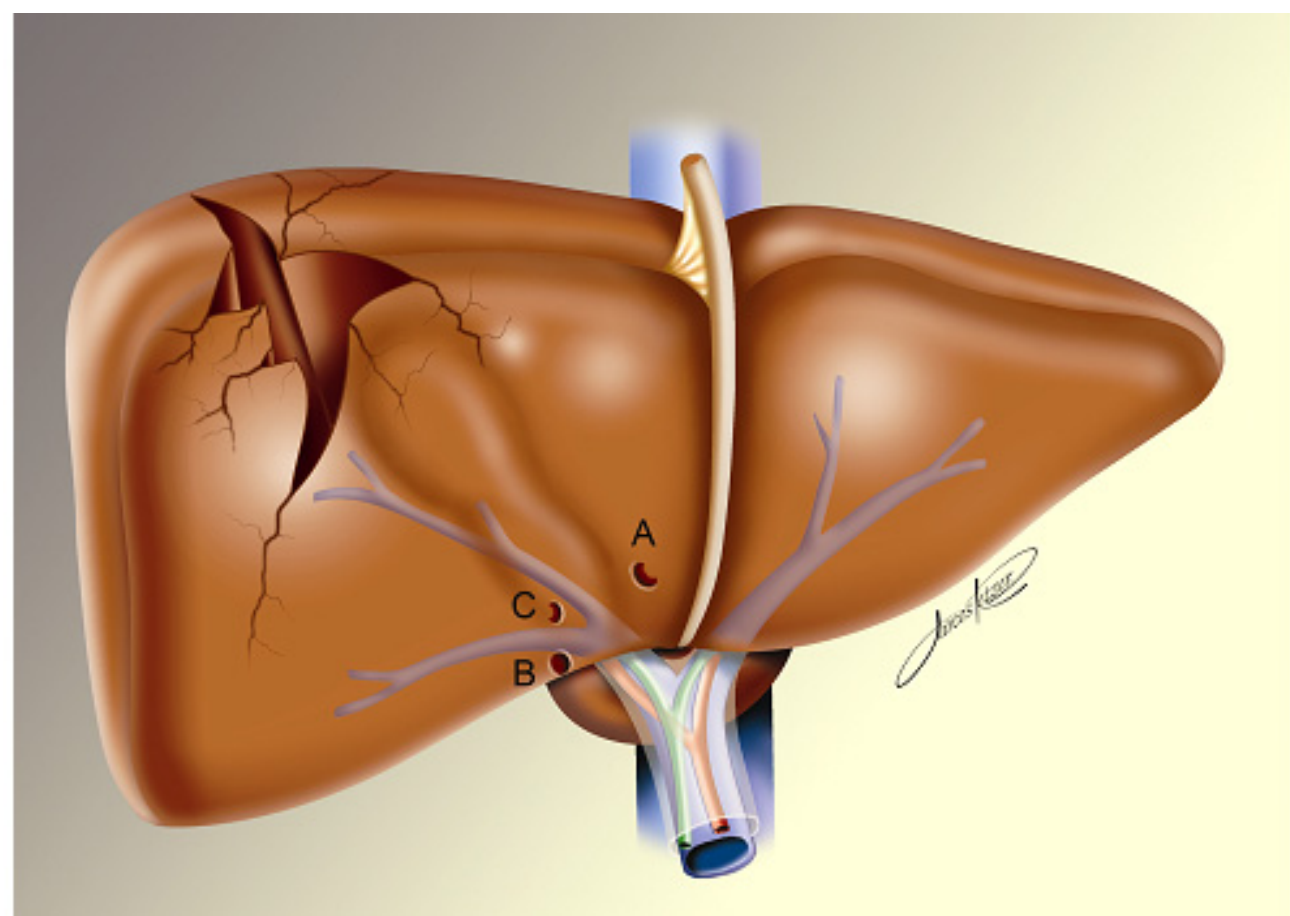

FIGURE 1 - Incisions for the intrahepatic approach of the Glisson pedicle and the angles to isolate the sheaths.

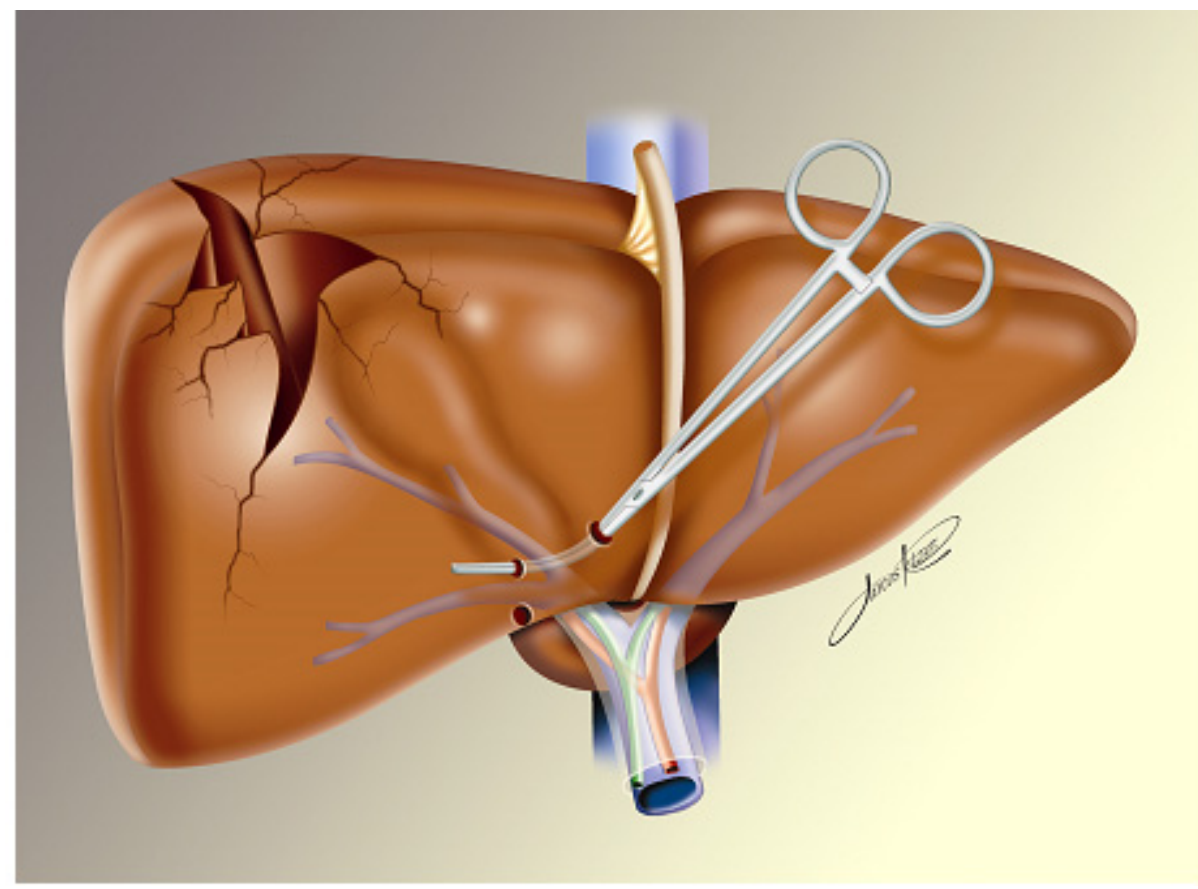

FIGURE 2 - View of the anterior pedicle dissection containing the portal triad for the segments $\mathrm{V}$ and VIII. 
lobe is then pulled upward and the lesser omentum is divided exposing the arantius ligament (ligamentum venosum). This ligament runs from the left branch of the portal vein to the left hepatic vein or to the common trunk, which makes it a useful anatomical landmark for the identification of the left hepatic and portal veins.

The Arantius ligament is then encircled and divided. The cephalad stump can be used to dissect the left hepatic vein and the common trunk. The caudal stump of the ligament (Figure 3 ) is grasped and dissected downward toward the left portal vein. This maneuver discloses the posterior aspect of the left glissonian pedicle. A small $(3 \mathrm{~mm})$ anterior incision is made in front of the hilum (figure 4) and a large curved clamp (mixter or Gray) is introduced through the left side of the left glissonian sheath behind the caudal stump of the Arantius ligament toward the anterior incision (figure 5) allowing the encircling of the left main sheath. This maneuver spares the caudate lobe (segment I) portal branches.

The round ligament is then retracted upward, exposing the umbilical fissure between segments III and IV. In about one third of the patients, a parenchymal bridge connecting these 2 segments is present and must be divided. Using the round ligament as a guide, 2 small incisions (figure 5, sites $\mathrm{C}$ and $\mathrm{D}$ ) are performed on the left and right margins of the round ligament where it is possible to identify the anterior aspect of the glissonian pedicle of segment IV on its right side and segment III on its left side. With a clamp introduced through incisions $\mathrm{B}$ and $\mathrm{C}$, it is possible to isolate the glissonian pedicle of the left medial sector or segment IV. By combining incisions A and D (figure 5), it is possible to isolate the glissonian pedicle of the left lateral sector (segments II and III). Another small incision can be performed midway between incisions D and A (figure 5), permitting individual access either to segments II or III, allowing monosegmentectomies to be perform. All these steps are performed without hilar dissection or clamping.

\section{DISCUSSION}

The advances in diagnostic tools, like high definition CT scans and the concepts of nonoperative management of the hemodynamicaly stable patients

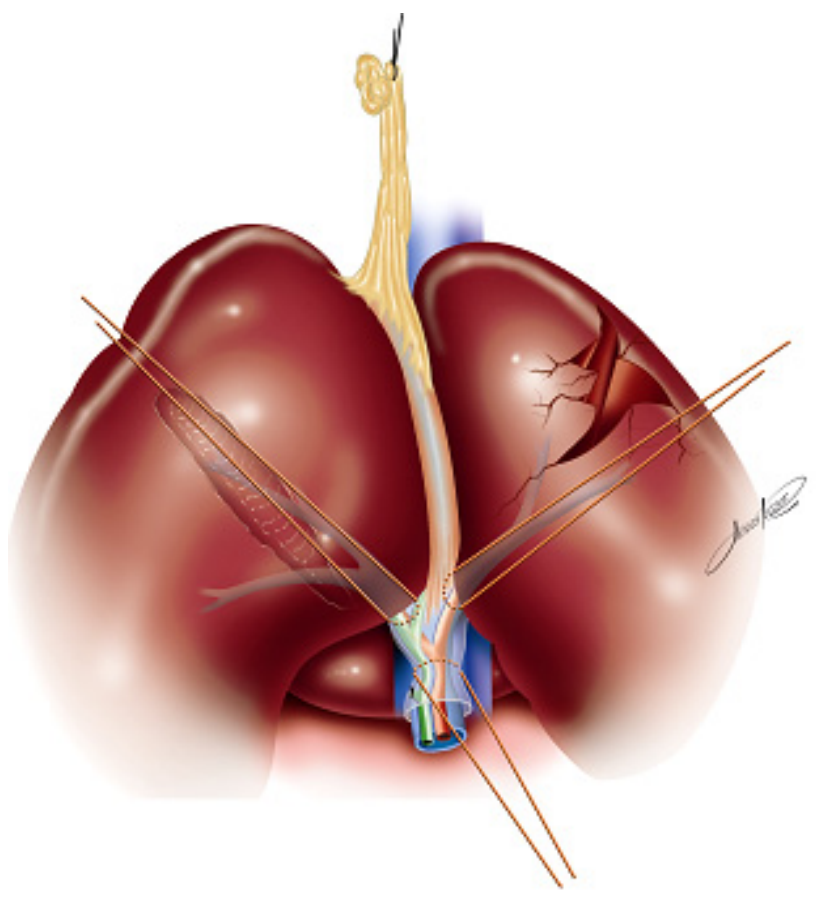

FIGURE 3 - Landmarks for the intrahepatic approach of the Glisson pedicle of the left lobe and its segments. When clamp is passed from $A$ to $B$ it provide access to the main sheath. Site $A$ to $D$ access to segments II and III; site E to A - access to segment II; site $D$ to $E$ - segment III and Site C to D - segment IV.

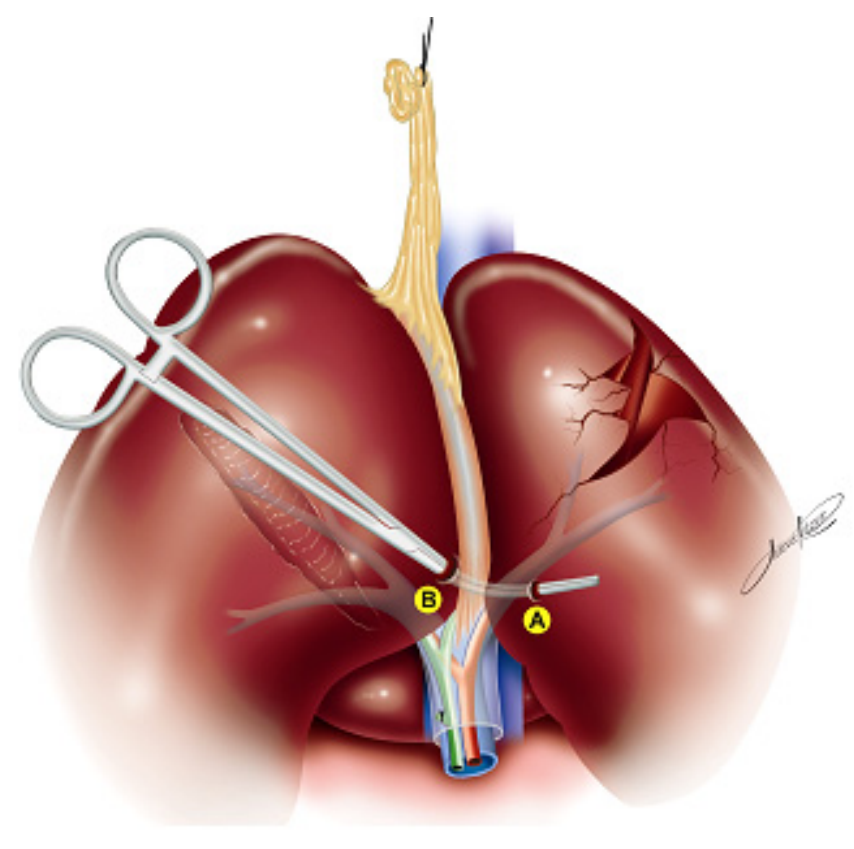

FIGURE 4 - Landmarks for the intrahepatic approach of the Glisson pedicle of the left lobe and its segments. When clamp is passed from $A$ to $B$ it provide access to the main sheath containing the arterial, portal and bile ducts branches of segments II, III and IV 


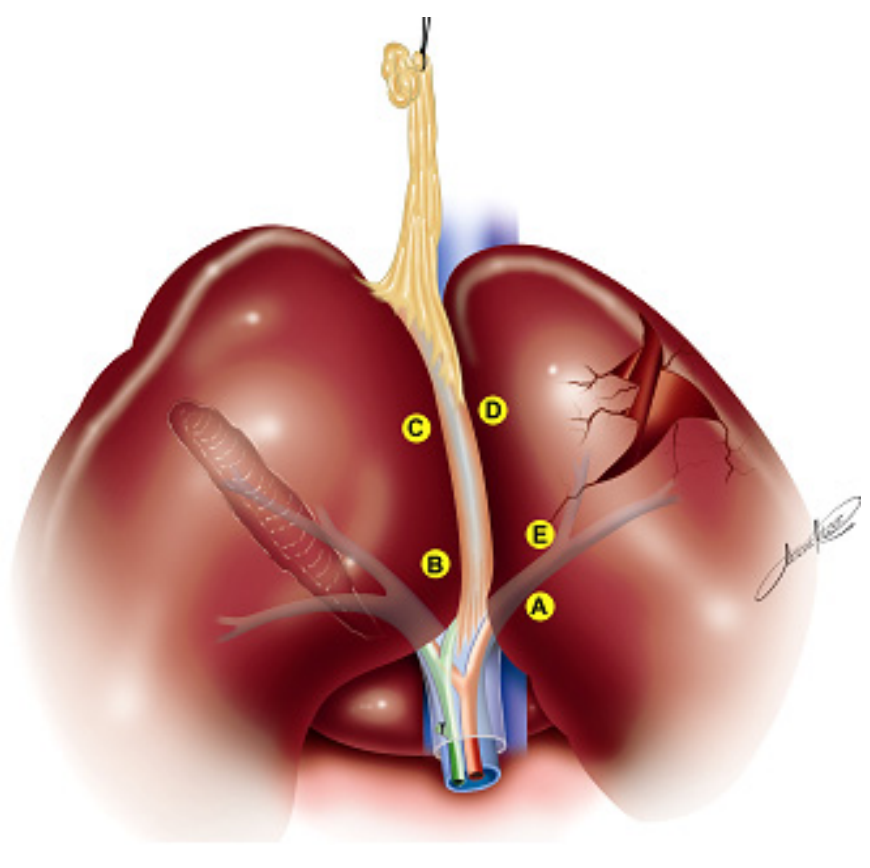

FIGURE 5 -left liver segments approach .

with blunt and even sometimes with well located right upper quadrant penetrating injuries ${ }^{9}$, has become the standard of care in most trauma centers all over the world. The reason for the conservative management is well known, and according to Fabian et al ${ }^{10}$, more than $80 \%$ of the liver injuries have stopped bleeding by the time of laparotomy and in addition to that, the bile ducts injuries rarely results in abdominal infections.

However, there are still a significant number of cases who fail the nonoperative approach, due to the complexity of the trauma. In grades I to III the numbers are around 3 to 7,5\%, and in lesions grades IV and $\mathrm{V}$ it can get as high as 14 to $52 \%$ of the initial nonoperative approach group ${ }^{11,12}$.

Several surgical approaches have been described to handle this usually very stressful situation, and the trauma surgeon must be familiar with at least some of them in order to be able to provide a quality care for the patient.

Most of the minor liver injuries do not require any kind of fixation and nonbleeding wounds does not need to be manipulated. The small liver wounds can be fixed using the eletrocautery, argon bean or even little suture lines grabbing the injured site that can be anchor by omentum strips, if possible from the right side of the greater omentum sac. ${ }^{13,14}$
Hirshberg and Mattox well stated the fundamental steps to handle a grade IV or V hepatic injury during laparotomy. It starts with control of the bleeding that can usually achieve by manual compression, temporary packing and Pringle maneuver. Unfortunately sometimes theses maneuvers fails and bleeding continues.

\section{Table 2}

Direct approaches to liver trauma
1- Electrocautery devices
2-Argon Beam
3- Hemostatic agents
4 - Hepatorrhaphy with large curved needles
5-Angiography with selective embolization
6-Hepatotomy with selective vascular ligation
7- Viable omental pedicle
8- Ballon tamponade
9- Resectional debridement

In this situation there are basically three possible reasons for ongoing hemorrhage ${ }^{13}$ : Arterial bleeding that is usually not controlled by liver packing, anatomical variation from the arterial supply or retrohepatic venous injuries.

Several approaches can be used in hepatic trauma as presented in table 2. The glissonian approach represents one alternative to the surgeon who domains both anatomical and surgical skills to treat a liver injury trying to decrease the complications related to non-anatomical resections, deep parenchyma unselective sutures leading to necrosis without infection presented as the known "liver fever", and even worst complications like hepatic liver failure due to inadequate remaining liver volumes.

Situations where bleeding comes from the deep part of the parenchyma, especially the arterial bleedings, instead of trying to close the hole to stop the bleeding it is advocated to open the wider to achieve the bleeding source and control it. In this kind of scenario a temporary manual compression and pedicle control may be a good option since the surgeon will be able to have an adequate vascular inflow control without compromising other sectors of the liver. Another 
indication is to achieve hemostasis in the raw surface of the liver after a partial avulsion of the liver tissue, trying to obtain a more homogeneous and clear margin.

In elective liver surgery the glissonian approach has been used for several years, permitting an aggressive approach to liver tumors while preserving as much a possible parenchyma, especially because these patients may require in the future new resections, ablative therapies as well as aggressive chemotherapy regimens that may be compromise the liver function.

Machado et al ${ }^{6,7}$, described two series of right and left lobe hepatic resections either to treat primary liver cancer and liver metastasis, varying from monosegmental resections, left and right trisegmentectomies to mesohepatectomies without technical related complications, no blood transfusion and no mortality. Batignani ${ }^{15}$ reported this approach in seven patients, four cirrhotic, with good results and no need for blood transfusion, been able to perform elective resection in all his cases. The mean time required to achieve right portal pedicle control was 14 minutes (range 5 to 24 minutes). Obviously in trauma surgery time is always a concern, especially in liver trauma, with the increasing experience of our group with this kind of approach and the correct anatomic landmarks, the glissonian approach can be done safely in few minutes without any additional harm.

\section{CONCLUSION}

In conclusion, the presentation of the glissonian approach represents today another tool that can be used by the trauma surgeons in order to perform anatomical liver resections in the trauma setting in order to minimize the complications related to the non-anatomical removal of parenchyma and blinded-ligatures as well as the well known ischemia- reperfusion injuries and its consequences, specially to the recover of the liver parenchyma.

\begin{abstract}
AIM: To investigate a different approach in liver trauma, that preserves as much liver parenchyma as possible, exposing only the injured area to ischemia and reperfusion. MATHERIAL AND METHODS: Medline and pubMed search from 1980 to 2010 about the glissonian approach , including, liver, surgery, trauma, portal vein and hepatic artery as key-words.RESULTS: The glissonian approach is feasible, not technically demanding, and the key for the success is the knowledge of the anatomical landmarks in the liver surface, to facilitate the surgeon to obtain a fast control of the injured area without compromising the liver flow to the non traumatic area. CONCLUSION: The glissonian approach represents another tool that can be performed in liver trauma setting to minimize complications related to the non-anatomical removal of parenchyma and blinded-ligatures
\end{abstract}

Key Words: Liver. Trauma. Surgery. portal vein. hepatic artery.

\section{REFERENCES}

1- Croce MA, Fabian TC, Menke PG - Nonoperative management of blunt hepatic trauma is the choice for hemodinamically stable patients. Ann Surg 1995; 221:744-753 [PMID: 7794078 DOI: doi:10.1097/00000658-199506000-00013]

2- Moore EE, Cogbill TH, Jurkovitch GJ, Shackford SR, Malangoni MA - Organ injury scaling-spleen, liver (1994rev). J Trauma 1995; 38:323-4. [PMID: 7897707 DOI: 10.1097/00005373199503000-00001]

3 - Abdalla EK, Adam R, Bilchik AJ, Jaeck D, Vauthey JN, Mahvi D. - Improving respectability of hepatic colorectal metastases: Expert consensus statement. Ann Surg Oncol Oct 2006; 13(10):1271-80. [PMID: 16955381 DOI: doi:10.1245/s10434006-9045-5]

4 - Galperin EI, Karagiulian SR - A new simplified method of selective exposure of hepatic pedicles for controlled hepa- tectomies. HPB Surg 1989; 1:119-130. [PMID: 2487059 DOI:10.1155/1989/28161]

5- Launois B, Jamieson GG - The posterior intrahepatic approach for hepatectomy or removal of segments of the liver. Surg Gynecol Obstet 1992; 174:155-158. [PMID: 1734576]

6 - Machado MAC, Herman P, Machado MCC - A standardized technique for right segmental liver resections. Arch Surg 2003; 138:918-920. [PMID:12912755 DOI: 10.1001/ archsurg.138.8.918]

7 - Feliciano DV, Mattox KL, Jordan GL Jr, Burch JM, Bitondo CG, Cruse PA. Management of 1000 consecutive cases of hepatic trauma (1979-1984). Ann Surg. 1986 Oct;204(4):438445. [PMID:3767479 DOI: 10.1097/00000658-19861000000012]

8- Machado MAC, Herman P, Machado MCC - Anatomical resection of left liver segments. Arch Surg 2004; 139:1346-1349. [PMID:15611460 DOI: 10.1001/archsurg.139.12.1346] 
9 - Demetriades D, Gomez H, Chahwan S, Charalambides K, Velmahos G, Murray J, Asensio J, Berne TV - Gunshot injuries to the liver: the role of selective nonoperative managment. J Am Coll Surg 1998; 188:343-348. [PMID: PMID: 10195716 DOI: $10.1016 / S 1072-7515(98) 00315-9]$

10 - Fabian TC, Bee TK - Liver and biliary tract trauma. In: Trauma. Magre, Feliciano, Mattox. 5th Ed. Trauma. Norwalk: Appleton\&Lange; 2003, 637-61.

11 -Malhotra AK, Fabian TC, Croce MA, Gavin TJ, Kudsk KA, Minardi G, Pritchard FE - Blunt hepatic injury: a paradigm shift from operative to nonopeerative management in the 1990s. Ann Surg 2000; 231:804-13. [PMID: 10816623 DOI: 10.1097/00000658-200006000-00004]

12 - Kozar RA, Moore FA, Cothren CC, Moore EE, Sena M, Bulger EM, Miller CC, Eastridge B, Acheson E, Brundage SI, Tataria M, Mc Carthy M, Holcomb JG - Risk factors for hepatic mor- bidity following nonoperative management: multicenter study. Arch Surg 2006; 141:451-8. [PMID: 16702516 DOI: 10.1001/ archsurg.141.5.451]

13 - Hirshberg A, Maatox KL - The injured liver: Ninja Master. In: Top Knife-the art \& craft of trauma surgery. Hirshberg \& Maatox. 1st Ed. Castle Hill Barns: tfm Publishing; 2006, 8398.

14 - Stracieri LDS, Scarpelini S - Hepatic injury. Acta Cir Bras 2006; Supl 1:85-88.

15 - Batignani G - Hilar plate detachment and extraglissonian extrahepatic anterior approach to the right portal pedicle for right liver resections. J Am Coll Surg 2000; 190:631-634. [PMID: 10801032 DOI: 10.1016/S1072-7515(00)00254-4] 